Annals of Warsaw University of Life Sciences - SGGW

Horticulture and Landscape Architecture No 41, 2020: 51-62

(Ann. Warsaw Univ. of Life Sci. - SGGW, Horticult. Landsc. Architect. 41, 2020)

DOI 10.22630/AHLA.2020.41.5

\title{
The evaluation of infection caused by different fungi species of highbush blueberry plants grown on selected commercial plantations located in central Poland
}

\author{
WIOLETA LIDIA PIENCEK, WOJCIECH KUKUŁA \\ Institute of Horticultural Sciences, Warsaw University of Life Sciences - SGGW
}

\begin{abstract}
The evaluation of infection caused by different fungi species of highbush blueberry plants grown on selected commercial plantations located in central Poland. In the years 2017-2018, research was carried out on the occurrence of fungal diseases on four plantations of highbush blueberry plants located in central Poland. The aim of the research was to isolate and identify pathogens from diseased parts of plants of highbush blueberry. Four fungi species were identified based on traditional methods with mycological keys - visible symptoms were present on infected parts of the plants and the morphology structure. On all of the tested plantations, symptoms of Botrytis cinerea, Godronia cassandrae and Phomopsis vaccinii were observed. The Valdensia heterodoxa like symptoms were observed too, but only once. The second part of the research was an evaluation of the effectiveness of seven fungicides in control of grey mould disease of highbush blueberry. The research was conducted using both pesticides commonly recommended for the protection of highbush blueberry plantations against grey mould disease as well as fungicides permitted for use on other berry plants (strawberry and raspberry). The fungicides Luna Experience $400 \mathrm{SC}$ and Prolectus $50 \mathrm{WG}$ can be considered as an addition to the list of pesticides recommended for the control of grey mould disease.
\end{abstract}

Key words: Vaccinium corymbosum L., fungal diseases, chemical control, Botrytis cinerea, Godronia cassandrae, Phomopsis vaccinii, Valdensia heterodoxa

\section{INTRODUCTION}

Highbush blueberry (Vaccinium corymbosum L.) belongs to the family Ericaceae. It comes from North America and is considered relatively new, especially in Europe (Zmarlicki 2006). Poland ranks third in terms of blueberry production, after the USA and Canada (Strojewska 2017). Due to favourable climate and soil conditions, high fruit prices and their health-promoting properties, the acreage of highbush blueberry is growing systematically every year (Smolarz et al. 2006). The most serious threat in the cultivation of blueberries is diseases caused by fungi: grey mould, anthracnose, shoot canker, shoot dieback and leaf blotch. The perpetrators of the above diseases cause many economic losses related to its cultivation, among others a decrease in yield of at least 50\% (Polashock et al. 2005, Zalewska et al. 2007, Meszka and Bielenin 2012). Disease symptoms caused by fungi are varied and depend on the variety and its susceptibility to the pathogen, as well as on atmospheric-growing conditions (Polashock et al. 
2005, Zalewska et al. 2007). Grey mould is caused by Botrytis cinerea. Symptoms of the disease appear on shoots in the form of necrosis of their tips. Leaves, flowers and fruit are infected and show dry, brown necrosis (Caruso and Ramsdell 1995). Fungi of the genus Colletotrichum cause anthracnose, which is visible on all the above-ground organs of the plant. The most dangerous infections caused by Colletotrichum spp. are those found on fruits. In 2006, there was a significant increase in the occurrence of highbush blueberry anthracnose in Polish plantations. It was favoured by high air humidity, temperatures in the range of $20-27^{\circ} \mathrm{C}$, and an intensive replacement of planting material (Meszka and Bielenin 2012). Godronia canker, caused by the fungus Godronia cassandrae Peck., may cause stem dieback in highbush blueberry. It is the most common disease of highbush blueberry shoots in Poland (Szmagara 2009). Young plantations must be protected in a peculiar way, as one-year and two-year-old shoots are the most often attacked. Infections of young shoots occurs through mechanical damage, leaf scars, and cracks in the bark, sometimes freely through the peel. These infections occur both during the growing season and during rest, when there is an appropriate climate favourable for the development of the fungus (a wet and warm winter) (Stromeng and Stensvand 2011). Phomopsis vaccinii Shear is the cause of stem and shoot dieback in highbush blueberry crops. Infections by Phomopsis vaccinii are also observed on fruits, causing them to rot. These infestations can cause a significant drop in yield. From the infected flower, the infection progresses to the shoot, where necrosis or gangrene appears. Infection by Valdensia heterodoxa Peyronel can lead to a too early defoliation of plants and a reduction in yield in the next season, due to plant secondary growth at the expense of flower buds. Diseases of fungal origin are widespread all over the world and cause the greatest losses to plant crops (Dzięcioł et al. 2014).

In particular, it is the chemical method that is used to control diseases on blueberry plantations. The range of registered fungicides is limited, so it is necessary to search for new pesticides with high efficiency. The threat of pathogens resistance to available active substances increases, and therefore, as part of the anti-resistance strategy, the possibility of using agents from various chemical groups should be analysed. The use of the same active substances and even the same chemical groups leads to the production of resistant breeds by fungi, which results in decreasing the effectiveness in combatting fungal diseases (Avenot and Michailides 2010).

Interest in the synthesis of new active substances from the group of succinic acid dehydrogenase (SDHI) inhibitors is increasing. The advantage of the above substances is their wide range of action, high effectiveness in low doses and an avoidance of the risk of resistance in the fungal pathogens (Avenot and Michailides 2010).

The aim of the study was the evaluation of infection with different fungi species of highbush blueberry plants grown on selected commercial plantations located in central Poland.

The scope of work included: (i) lustration of highbush blueberry plants growing on selected production planta- 
tions on three dates; (ii) collection of infected plants organs with visible symptoms; (iii) identification of causal agents of diseases on highbush blueberry plants based on traditional methods; (iv) evaluation of the effectiveness of selected fungicides in relation to the BCZ3 Botrytis cinerea isolate.

\section{MATERIAL AND METHODS}

Identification of pathogens inhabiting highbush blueberry plants based on macroscopic observations

The research was conducted in 2017-2018 at the Department of Plant Pathology at Warsaw University of Life Sciences - SGGW. Material for research was collected from commercial plantations located in: the Mazowieckie $\left(52^{\circ} \mathrm{N}, 21^{\circ} \mathrm{E}\right)$ (single plantation) and Łódzkie $\left(51^{\circ} \mathrm{N}\right.$, $\left.19^{\circ} \mathrm{E}\right)$ Voivodships (three plantations). Observations were carried out on 100 selected plants of each of the highbush blueberry cultivars on three dates: in autumn, spring and summer, using the topographic method. During lustrations, the shoots (in autumn), leaves and flowers (in spring), and leaves and fruits (in summer) were collected for testing, and placed in parchment bags. Next, those collected plants tissues with visible symptoms were used for identification of the causal agent.

The percentage of infestation was calculated according to the following formula:

percentage of infestation $=\frac{X_{1}}{X_{0}} 100$

$X_{1}$ - number of infested plants, $X_{0}-$ number of observed plants.
Identification of causal agents of diseases on highbush blueberry plants based on traditional methods

Plant tissues with visible symptoms of disease were observed under the stereoscopic microscope ZS11 (Olympus). Morphological structures from the surface of the tissues were compared to them in mycological keys. To obtain isolates of the causal agent of diseases, 2-3 $\mathrm{mm}$ sections from the leaf spot were cut out. After disinfection with $1 \%$ sodium hypochlorite, the sections were transferred into $10 \mathrm{~cm}$ Petri dishes with PDA. Next, they were kept for a few days at $20^{\circ} \mathrm{C}$ in daylight (Amiri et al. 2018).

The obtained isolates were used also in a pathogenicity test. Hyphae fragments and other morphological structures were analysed using an Olympus BX50 light microscope equipped with a DP71 camera. The CellF program was used to take pictures and measure the morphological structures.

The obtained isolates were transferred to new Petri dishes with PDA and were collected for other assays.

\section{The impact of fungicides on hyphae growth in laboratory conditions}

A seven-day culture of the obtained isolate BCZ3 identified as B. cinerea was used for the fungicide test in the second part of the study. In this assay fungicides selected on the basis of the Highbush Blueberry Plant Protection Programme (Kupczak 2018) and the list of authorised products located on the website of the Ministry of Agriculture and Rural Development were used. This scope has been extended by the active substances described in publications by Meszka and 
TABLE 1. List of fungicides and active substances used in the study

\begin{tabular}{|c|c|c|}
\hline Fungicide name & Active ingredient & $\begin{array}{c}\text { Recommended dose for a single } \\
\text { use }\end{array}$ \\
\hline \multicolumn{3}{|c|}{ List of fungicides authorised for use on highbush blueberry plants } \\
\hline Teldor $500 \mathrm{SC}$ & fenhexamid $-500 \mathrm{~g}$ & $1.5 \mathrm{~L} \cdot \mathrm{ha}^{-1}$ \\
\hline \multirow{2}{*}{ Signum $33 \mathrm{WG}$} & boscalid $-26.7 \%$ & \multirow{2}{*}{$15 \mathrm{~g} \cdot 100 \mathrm{~m}^{-2}$} \\
\hline & pyraclostrobin $-6.7 \%$ & \\
\hline Topsin M 500 SC & thiophanate methyl $-500 \mathrm{~g}$ & $\begin{array}{c}1.5 \mathrm{~L} \cdot \mathrm{ha}^{-1} \\
15 \mathrm{~mL} \cdot 100 \mathrm{~m}^{-2}\end{array}$ \\
\hline \multirow{2}{*}{ Switch 62,5 WG } & cyprodinil - $375 \mathrm{~g}$ & \multirow{2}{*}{$10 \mathrm{~g} \cdot 100 \mathrm{~m}^{-2}$} \\
\hline & fludioxonil $-250 \mathrm{~g}$ & \\
\hline Biszop $80 \mathrm{WG}$ & captan $-800 \mathrm{~g}$ & $1.9 \mathrm{~kg} \cdot \mathrm{ha}^{-1}$ \\
\hline \multicolumn{3}{|c|}{ List of fungicides authorised for use on other berry plants } \\
\hline \multirow{2}{*}{ Luna Experience $400 \mathrm{SC}$} & fluopyram $-250 \mathrm{~g}$ & \multirow{2}{*}{$0.6 \mathrm{~L} \cdot \mathrm{ha}^{-1 *}$} \\
\hline & tebuconazole $-200 \mathrm{~g}$ & \\
\hline Prolectus $50 \mathrm{WG}$ & fenpyrazamina $-500 \mathrm{~g}$ & $1.2 \mathrm{~kg} \cdot \mathrm{ha}^{-1 * *}$ \\
\hline
\end{tabular}

*The recommended dose is for one-time use in the cultivation of raspberry.

**The recommended dose is for one-time use in the cultivation of strawberry.

Bielenin (2011), and Broniarek-Niemiec and Meszka (2015) - Table 1.

Fungicide tests were carried out in $5 \mathrm{~cm}$ Petri dishes with PDA (control combination) and PDA with the addition of the fungicides in such volumes that the active substance content was 0.001 , 0.01 , and $0.1 \mathrm{~g} \cdot \mathrm{L}^{-1}$. The active substances were selected on the basis of literature studies (Meszka and Bielenin 2011, Amiri et al. 2013) and the Blueberry Plant Protection Programme (Kupczak 2018) in accordance with the labels approved by the Ministry of Agriculture and Rural Development. In the centre of the dishes a mycelial section of agar cut from a Petri dish with a culture of $B$. $c i$ nerea using a sterile preparation needle was placed. Petri dishes were placed on a table in a growth chamber where the temperature was $25^{\circ} \mathrm{C}$. A total of 80 Petri dishes were used, of which five were the control combination. The experiment was performed in duplicate. After four days of incubation, when the $B$. cinerea culture had overgrown the entire surface of the medium in the control dish, the mycelium diameter was measured in combination with the fungicides. The percentage of mycelial growth inhibition was calculated according to the following formula:

percentage of mycelial growth inhibition $=$ $=\frac{K_{0}-F}{K_{0}} 100$

$K_{0}$ - diameter of $B$. cinerea culture in control combination,

$F$ - diameter of $B$. cinerea in combination with the selected fungicide. 


\section{RESULTS AND DISCUSSION}

\section{The evaluation of infection with different fungi species of highbush blueberry plants based on macroscopic observations}

On plant material collected from 315 plants of highbush blueberry: Botrytis cinerea, Phomopsis vaccinii and Godronia cassandrae were confirmed. The percentage of symptoms observed macroscopically on highbush blueberry plants during the conducted lustration was variable. Canker and twig dieback were observed on the plantations in autumn, twig shoots and buds in spring, and fruit rot in summer. Some shoots were heavily infected, causing whole plants to wilt. During the spring lustration of the bushes, necrosis, cracks in the bark, and dying off of flower buds and flowers were observed. During the summer lustration, infected fruits were observed lying on the ground. The fruit was soft and had turned reddish brown in colour. The test results were characterised by means of graphs showing the ratio of healthy plants to diseased plants (Figs. 1-3).

On the plantation located in the Mazowieckie Voivodeship, brown, concentrically zoned spots surrounded by a dark purple border were observed. Conidial structures located in the centre of the spots suggested that it was Valdensia heterodoxa. In the conducted research, the variety on which brown spot was observed was not recognised. Similar symptoms on blueberry leaves were observed by Peyronel (1923) and Nekoduka (2012). Symptoms of blueberry blotch in Poland in Mazovia Region were previously recorded by Dzięcioł et al. (2014) for cv. Bluecrop and Kukuła et al. (2017) for cv. Bluegold.

The conducted lustration confirmed the occurrence of fungal diseases on highbush blueberry plants. Similar disease symptoms were observed as those previously reported by other researchers on plants cultivated in other regions of the country (Machowicz-Stefaniak and Zalewska 2001, Szmagara 2009, Kukuła and Mirzwa-Mróz 2015) and the world - Canada, the USA, Norway, Russia

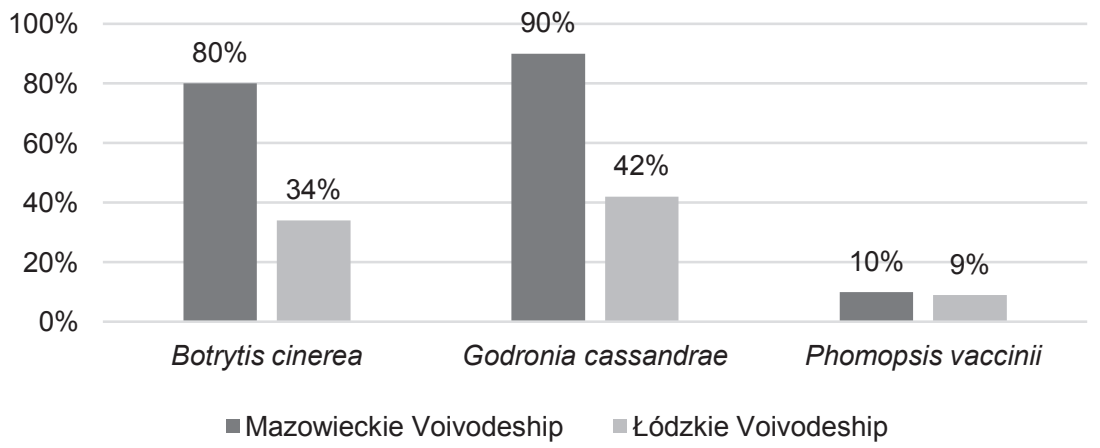

FIGURE 1. Percentage of infection of highbush blueberry plants cv. Bluegold, Chandler, Duke, Earliblue, Bluecrop, Jersey, growing on plantations in the Mazowieckie and Łódzkie Voivodeships in autumn 


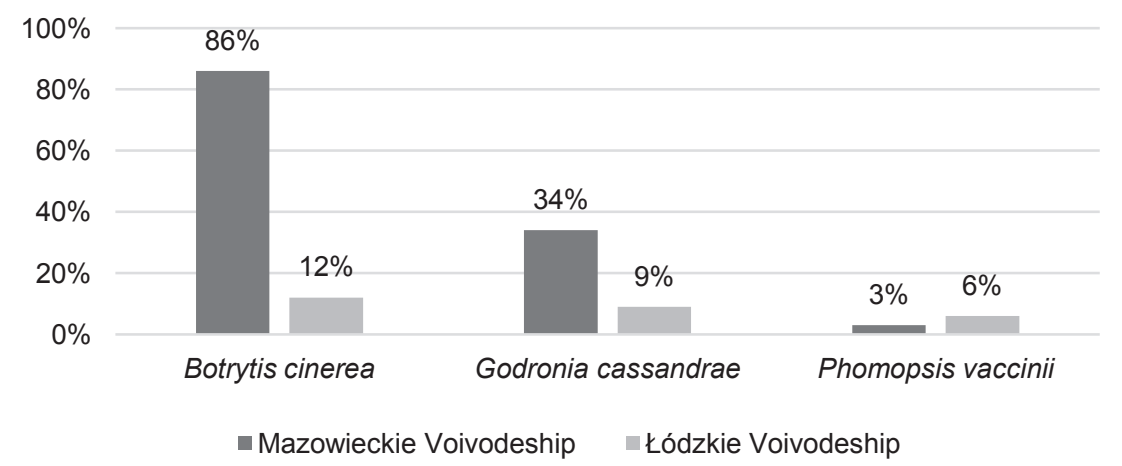

FIGURE 2. Percentage of infection of highbush blueberry plants cv. Bluegold, Chandler, Duke, Earliblue, Bluecrop, Jersey, growing on plantations in the Mazowieckie and Łódzkie Voivodeships in spring

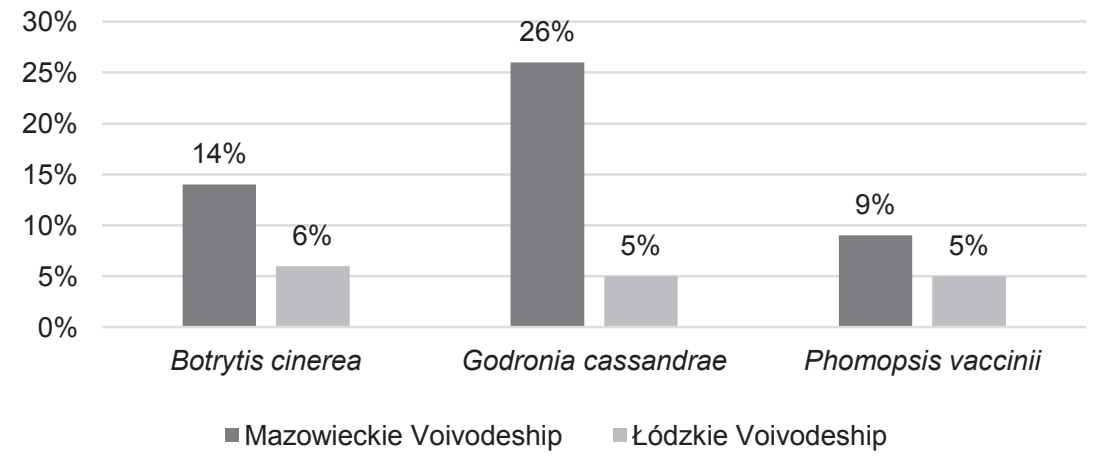

FIGURE 3. Percentage of infection of highbush blueberry plants cv. Bluegold, Chandler, Duke, Earliblue, Bluecrop, Jersey, growing on plantations in the Mazowieckie and Łódzkie Voivodeships in summer

(Caruso and Ramsdell 1995, Stromeng and Stensvand 2001).

In the research carried out by Kućmierz et al. (2013) in Lesser Poland, cv. Bluecrop, Darrow and Jersey were the most susceptible to diseases, while the cultivars Bonifacy and Brigitta were the least sensitive. In the conducted research, carried out in the Mazowieckie and Łódzkie Voivodships, the cultivars Bluecrop, Bluegold, Jersey and Earliblue were the most susceptible to diseases. On highbush blueberry cv. Bluecrop and Bluegold, necrosis and gan- grene of the shoots were observed, with the percentage of infection amounting to $20 \%$ and $90 \%$, respectively. On the shrubs of the cultivars Earliblue and Jersey, the symptoms of grey mould disease were observed, with the percentages of infection being $18 \%$ and $20 \%$, respectively. On the shrubs of the cultivars Chandler and Duke were observed much less infestations of $3 \%$ and $4 \%$, respectively.

The percentage of infection of highbush blueberry plants growing on plantations in the Mazowieckie Voivodeship 
was larger than of the plants growing in Łódzkie Voivodeship. The perennial nature of blueberry cultivation on the plantation in Łódź and its location in the immediate vicinity of the forest are responsible for the higher percentage of infection.

\section{Identification of pathogens inhabiting highbush blueberry plants using traditional methods}

Identification of the species $B$. cinerea, $G$. cassandrae and $V$. heterodoxa was carried out on the basis of the morphological features produced by fungi, i.e. conidial spores.

Godronia cassandrae: The conidia $(n=100)$ were mostly two-celled, sometimes one-celled, narrow fusiform in shape, hyaline, and 7.5 to $14.1 \times 1.4$ to $4 \mu \mathrm{m}$ in size. The isolates were identified according to the description of Groves (1965) - Table 2.

Attempts to obtain cultures of fungal isolates grown on PDA failed.

Botrytis cinerea: The conidia $(n=100)$ were one-celled, ellipsoid or ovoid in shape, greyish brown, and 6.7 to $14.2 \times$ $\times 4.8$ to $8.5 \mu \mathrm{m}$ in size. The isolates were identified according to the description of Ellis and Waller (1974) - Table 3.

Attempts to obtain cultures of fungal isolates grown on PDA were successful. Thirty $B$. cinerea isolates were obtained.

Valdensia heterodoxa: Attempts to obtain cultures of fungal isolates grown on PDA were successful. One isolate of $V$. heterodoxa was obtained from the leaves of highbush blueberry, unknown cultivar. Based on the characteristic appearance of the spore, it was found to be $V$. heterodoxa (Fig. 4). Multicellular, hy-

TABLE 2. Comparison of morphological characteristics of the study isolate with respect to previously reported Godronia cassandrae

\begin{tabular}{|c|c|c|c|}
\hline \multicolumn{2}{|c|}{ Characteristics } & Present isolate* & Godronia cassandrae (Groves 1965) \\
\hline \multirow{6}{*}{ Conidia } & colour & hyaline & hyaline \\
\cline { 2 - 4 } & shape & $\begin{array}{c}\text { narrow fusiform, mostly straight, } \\
\text { mostly two-celled, sometimes } \\
\text { one-celled }\end{array}$ & $\begin{array}{c}\text { narrow fusiform, mostly straight, } \\
\text { mostly two-celled, sometimes } \\
\text { one-celled }\end{array}$ \\
\cline { 2 - 5 } & size $(\mu \mathrm{m})$ & $7.5-14.1 \times 1.4-4$ & $7-18 \times 1.5-3.5$ \\
\hline
\end{tabular}

*Average of the length and width measurement of 100 spores of Godronia cassandrae $(\mu \mathrm{m})$.

TABLE 3. Comparison of morphological characteristics of the study isolate with respect to previously reported Botrytis cinerea

\begin{tabular}{|c|c|c|c|}
\hline \multicolumn{2}{|c|}{ Characteristics } & Present isolate* & $\begin{array}{c}\text { Botrytis cinerea (Ellis and Waller } \\
1974)\end{array}$ \\
\hline \multirow{3}{*}{ Conidia } & colour & greyish brown & greyish brown \\
\cline { 2 - 4 } & shape & ellipsoidal or ovoid & ellipsoidal or ovoid \\
\cline { 2 - 4 } & size $(\mu \mathrm{m})$ & $6.7-14.2 \times 4.8-8.5$ & $6-18 \times 4-11$ \\
\hline
\end{tabular}

*Average of the length and width measurement of 100 spores of Botrytis cinerea $(\mu \mathrm{m})$. 


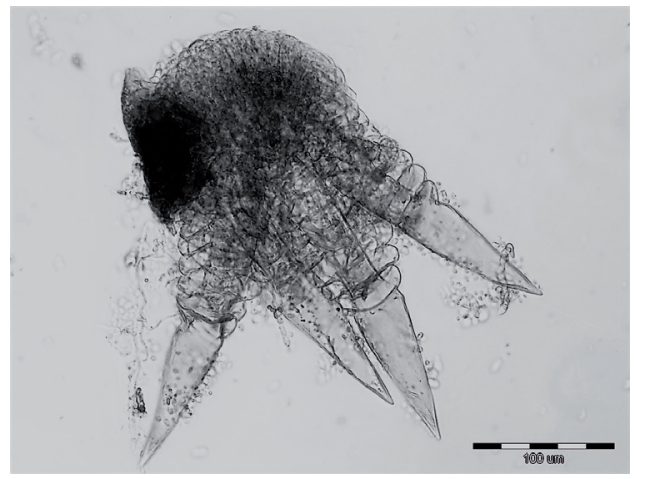

FIGURE 4. Conidial spore Valdensia heterodoxa (photo by W. Kukuła)

aline or light brown, star-shaped conidiospores were observed on the necrotic areas. Conidia were of $450-600 \mu \mathrm{m}$ in diameter. The isolates were identified according to the description of Mułenko and Woodward (1996) and Nekoduka et al. (2012).

Due to the absence of conidial spores on the collected plant material, $P$. vaccinii was not identified based on morphological features. P. vaccinii was identified on the basis of etiological signs present on infected plant organs. Disease symptoms were most often observed in autumn. Shoots affected by $P$. vaccinii initially took on a brown, then silver-grey necrosis. The pathogen penetrated into the highbush blueberry tissues mainly through shoot injuries and frost damage (Wilcox 1939, Weingartner and Klos 1975).

\section{Evaluation of the effectiveness of selected fungicides in relation to the $\mathrm{BCZ3} B$. cinerea isolate}

Active substances in the fungicides used for the study (Table 1) showed a positive effect in reducing the growth of $B$. cinerea colonies (Fig. 5).

Fungicides: Prolectus $50 \mathrm{WG}$, Luna Experience $400 \mathrm{SC}$, Teldor $500 \mathrm{SC}$, Switch 62.5 WG showed the strongest fungicidal activity compared to the tested BCZ3 isolate. Regardless of the concentration used, only the fungicide

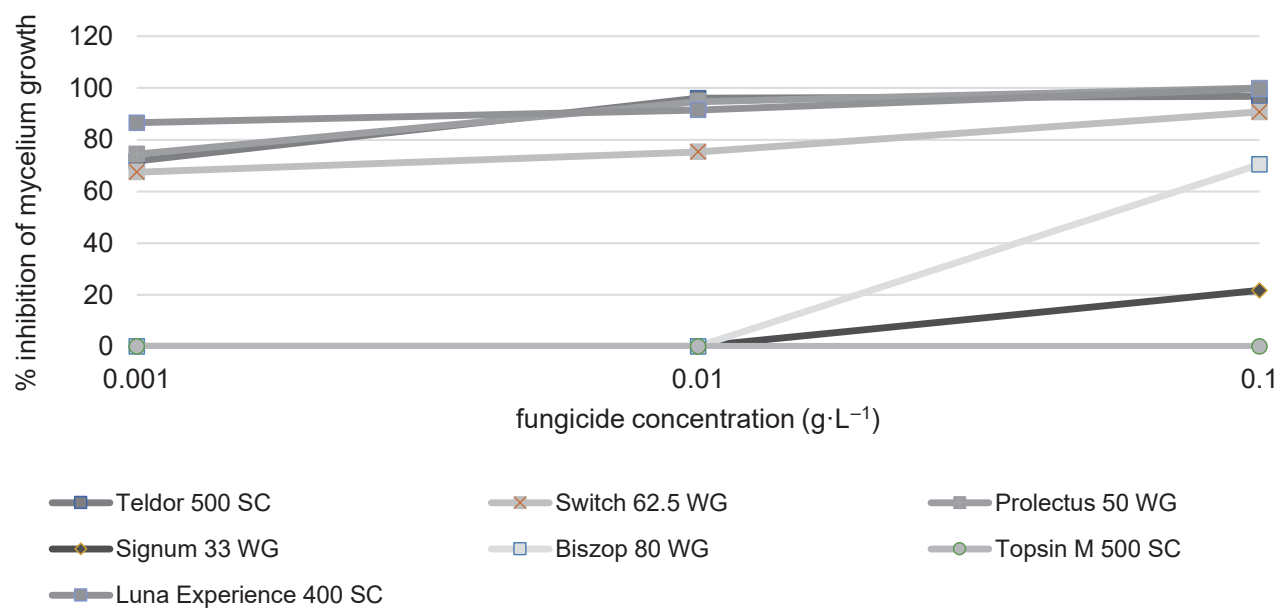

FIGURE 5. The effectiveness of the tested fungicides: Teldor $500 \mathrm{SC}$, Signum $33 \mathrm{WG}$, Topsin M 500 SC, Switch $62.5 \mathrm{WG}$, Biszop $80 \mathrm{WG}$, Luna Experience 400 SC, Prolectus $50 \mathrm{WG}$ in relation to the BCZ3 Botrytis cinerea isolate derived from the highbush blueberry plant cv. Bluecrop 
Topsin M 500 SC did not inhibit the growth of the mycelium of the $\mathrm{BCZ3}$ B. cinerea isolate.

The effectiveness of the unregistered fungicides (Prolectus $50 \mathrm{WG}$ and Luna Experience $400 \mathrm{SC}$ ) was very high in contrast to commonly used pesticides.

Highbush blueberry crops are threatened by fungal diseases - grey mould, anthracnose and diseases that cause shoot dieback. To combat these diseases, fungicides are used, including Switch 62.5 WG containing cyprodinil and fludioxonil. The preparation has a very good preventive effect (against fungal infection) and intervention effect (inhibiting mycelium growth after infection has already occurred). It can be used as needed throughout almost the entire growing season, up to seven days before harvest. The use of appropriate preparations against fungal diseases in the protection of highbush blueberry, even shortly before harvest (with a grace period), means that the content of its active substances in the fruit is significantly below the maximum permissible levels and thus safe for exporters and consumers. Weber (2011) found that $B$. cinerea is resistant to many fungicides, including compounds from the benzimidazole group, i.e. thiophanate methyl. Completely different results were obtained, however, in our own research, where, regardless of the concentration used, the Topsin M 500 SC fungicide did not inhibit the growth of mycelium of the BCZ3 isolate. Amiri et al. (2018) report that among all $B$. cinerea isolates taken for analysis, $93 \%$ showed high resistance to the active substance thiophanate-methyl, therefore Topsin M 500 SC fungicide is not effective against grey mould.
Weber (2011) reports that among all $B$. cinerea isolates taken for analysis, $45 \%$ of them showed high resistance to the active substance fenhexamide. Our experiments showed that the fungicide Teldor 500 SC very effectively inhibited the growth of $B$. cinerea mycelium. The effectiveness of the pesticides was over $96 \%$ in both the $10 \mathrm{ppm}$ and $100 \mathrm{ppm}$ fungicide concentrations.

Effectiveness tests of unregistered fungicides for use in our experiments showed the strongest activity of Luna Experience 400 SC and Prolectus $50 \mathrm{WG}$ on the tested isolate (BCZ3). The effectiveness of the pesticides in the doses of $10 \mathrm{ppm}$ and $100 \mathrm{ppm}$ was almost $100 \%$. In studies conducted by Broniarek-Niemiec (2015), Luna Sensation 500 SC was highly effective in combatting blackcurrant diseases. There is no information in the available literature on the performance of the Luna Experience $400 \mathrm{SC}$ and Prolectus $50 \mathrm{WG}$ in controlling blueberry grey mould.

Chemical methods are widely used in plantations, mainly due to the high availability of preparations and their satisfactory efficiency in comparison to agrotechnical and biological methods. Currently, protection against highbush blueberry anthracnosis in commercial plantations is carried out with the use of preparations containing captan, thiophanate-methyl, azoxystrobin and pyraclostrobin. Preparations from various chemical groups are registered to protect highbush blueberry against grey mould, e.g. compounds from the group of benzimidazoles (Teldor 500 SC), triazoles (Yamato $303 \mathrm{SE}$ ), strobilurin (Signum $33 \mathrm{WG}$ ), and phthalimides (Biszop $80 \mathrm{WG}$ ) (MRiRW 2018). The protection 
of highbush blueberry shoots is limited to preparations containing thiophanate-methyl and tetraconazole. In Poland, there are no registered preparations for combatting brown blotch in highbush blueberry leaves. Pristine WG fungicide is used in Canada. In Poland, such active substances are contained in Signum $33 \mathrm{WG}$, which is registered to combat grey mould (Kukuła and Mirzwa-Mróz 2015).

The most common disease in plantations was grey mould. The active substances used in the research showed a positive effect in reducing the spread of disease of grey mould in the cultivation of highbush blueberry plants. The effectiveness of unregistered fungicides (Prolectus $50 \mathrm{WG}$ and Luna Experience $400 \mathrm{SC}$ ) was very high in comparison to the commonly used preparations. Therefore, in addition to the recommended fungicides for controlling grey mould disease in highbush blueberry plantations, it is worth considering the possibility of using other chemical preparations from the SDHI and triazole groups.

\section{CONCLUSIONS}

1. The percentage of highbush blueberry plants infected with different fungi species depends on the highbush blueberry cultivar and plant development phase.

2. Highbush blueberry cultivars: Bluegold, Bluecrop, Jersey and Earliblue, show the greatest susceptibility to fungal diseases.

3. Plantation inspections, especially autumn, will contribute to limiting the development of fungal pathogens on highbush blueberry plants.
4. Chemical protection on highbush blueberry plantations can be extended by fungicides from the SDHI and triazole groups.

\section{REFERENCES}

AMIRI A., ZUNIGA A.I., PERES N.A. 2018: Potential Impact of Populations Drift on Botrytis. Occurrence and Resistance to Multi- and Single-Site Fungicides in Florida Southern Highbush Blueberry Fields. Plant Disease 102 (11). doi: 10.1094/PDIS-11-17-1810-RE

AMIRI A., HEATH S.M., PERES N.A. 2013: Phenotypic characterization of multifungicide resistance in Botrytis cinerea isolates from strawberry fields in Florida. Plant Disease 97: 393-401.

AVENOT H.F., MICHAILIDES T.J. 2010: Progress in understanding molecular mechanisms and evolution of resistance to succinate dehydrogenase inhibiting (SDHI) fungicides in phytopathogenic fungi. Crop Protection 29: 643-651.

BRONIAREK-NIEMIEC A. 2015: Luna Sensation 500 SC - nowy fungicyd do zwalczania chorób porzeczki czarnej [Luna Sensation $500 \mathrm{SC}$ - new fungicide for control of black currant fungal diseases]. Prog. Plant Prot. 55 (4): 478-482.

BRONIAREK-NIEMIEC A., MESZKA B. 2015: Możliwości integrowanej ochrony roślin jagodowych przed chorobami. In: Jubileusz 90. rocznicy urodzin prof. dr hab. Zbigniewa Boreckiego. Sesja Naukowa pt. "Aktualne problemy w ochronie drzew owocowych i krzewów jagodowych przed chorobami w Polsce". Samodzielny Zakład Fitopatologii Szkoły Głównej Gospodarstwa Wiejskiego i Oddział Warszawski Polskiego Towarzystwa Fitopatologicznego, Warszawa.

CARUSO F.L., RAMSDELL D.C. 1995: Phomopsis Canker. In: Compendium of Blueberry and Cranberry Diseases. APS Press, St. Paul, MN. 
DZIĘCIOE R., MIRZWA-MRÓZ E., ZIELIŃSKAE.,WIŃSKA-KRYSIAKM., WAKULIŃSKI W. 2014: Valdensinia heterodoxa Peyronel as a new pathogen of blueberry in Poland [online]. Plant Disease 98 (5): 688. doi: 10.1094/PDIS06-13-0644-PDN

ELLIS M.B., WALLER J.M. 1974: Sclerotinia fuckeliana (conidial state: Botrytis cinerea). CMI Descriptions of Pathogenic Fungi and Bacteria, No. 431. Commonwealth Mycological Institute, Kew.

GROVES J.W. 1965: The genus Godronia. Can. J. Bot. 43: 1195-1276.

KUĆMIERZ J., NAWROCKI J., SOJKA A. 2013: Podatność owoców kilkunastu odmian borówki wysokiej (Vaccinium corymbosum L.) na choroby. Prog. Plant Prot. 53 (4): 785-788.

KUKUŁA W., MIRZWA-MRÓZ E. 2015: Biology and epidemiology of Valdensinia heterodoxa Peyronel - pathogen of highbush blueberry. Prog. Plant Prot. 55 (2): 226-230.

KUKUŁA W., MIRZWA-MRÓZ E., WAKULIŃSKI W., PADUCH-CICHAL E. 2017: Characteristics of Valdensia heterodoxa Peyr. as an Ericaceaes pathogen in Poland. Acta Sci. Pol. Hortorum Cultus 16 (4): 101-112.

KUPCZAK K. 2018: Program Ochrony Roślin Sadowniczych. Plantpress. Kraków: 203-243.

MACHOWICZ-STEFANIAK Z., ZALEWSKA E. 2001: Grzyby zasiedlające nadziemne organy borówki wysokiej - Vaccinum corymbosum L. Ogólnopolska Naukowa Konferencja Ochrony Roślin Sadowniczych. ISiK, Skierniewice.

MESZKA B., BIELENIN A. 2011: Activity of laminarin in control of strawberry diseases. Phytopathologia 62: 15-23.

MESZKA B., BIELENIN A. 2012: Antraknoza borówki wysokiej, występowanie, szkodliwość i możliwości zwalczania. Prog. Plant Prot. 52 (1): 88-91.

MUŁENKO W., WOODWARD S. 1996: Plant parasitic hyphomycetes new to Britain. Mycologist 10: 69-72.
NEKODUKA S., KANEMATSU S., TANAKA K., HARADA Y., SANO T. 2012: Valdensinia leaf blight of blueberry caused by Valdensinia heterodoxa, a new fungal disease in Japan. J. Gen. Plant Pathol. 78 (3): 151-159.

PEYRONEL B. 1923: Sopra un singolare parassita polifago: Valdensia heterodoxa $\mathrm{n}$. gen et $\mathrm{n}$. sp. [On a singular polyphagous parasite: Valdensia heterodoxa n. gen. et n. sp.]. Staz. Speriment. Agr. Ital. 56: 521-538.

PLISZKA K., CLAYTON-GREENE K.A. 1993: The blueberry industry and research in Eastern Europe (review). Acta Horticulturae 346: 41-43.

POLASHOCK J.J., EHLENFELDT M.K., STRETCH A.W., KRAMER M. 2005: Anthracnose fruit rot resistance in blueberry cultivars. Plant Disease 89: 33-38.

SMOLARZ K., CHLEBOWSKA D., KRZEWIŃSKA D., KOZIŃSKI B. 2006: Przegląd badań nad oceną odmian borówki wysokiej prowadzonych od 1978 roku w Instytucie Sadownictwa i Kwiaciarstwa w Skierniewicach. Międzynarodowa Konferencja "Uprawa Borówki i Żurawiny". ISiK, Warszawa.

STROJEWSKA I. 2017: Owoce. Ceny detaliczne i spożycie. Rynek Owoców i Warzyw. Stan i Perspektywy 50: 26-29.

STROMENG G.M., STENSVAND A. 2001: Susceptibility of highbush blueberry (Vaccinium corymbosum L.) cultivars to Godronia canker (Godronia cassandrae f. sp. vaccini) in Norway. Gartenbauwissenschaft 66: 78-84.

STROMENG G.M., STENSVAND A. 2011: Godronia canker (Godronia cassandrae f. sp. vaccinii) in Highbush Blueberry. The European Journal of Plant Science and Biotechnology 5 (Special Issue 1): 35-41.

SZMAGARA M. 2009: Biodiversity of fungi inhabiting the highbush blueberry stems. Acta Sci. Pol. Hortorum Cultus 8 (1): 37-50.

WEBER R.W.S. 2011: Resistance of Botrytis cinerea to Multiple Fungicides in North- 
ern German Small-Fruit Production. Plant Disease 95: 1263-1269.

WEINGARTNER D.P., KLOS E.J. 1975: Etiology and symptomatology of canker and dieback diseases on highbush blueberries caused by Godronia (Fusicoccum) cassandrae and Diaporthe (Phomopsis) vaccinii. Phytopatology 65: 105-110.

WILCOX M.S. 1939: Phomopsis twig blight of blueberry. Phytopathology 29: 136-142.

ZALEWSKA E., KRÓL E., MACHOWICZ-STEFANIAK Z. 2007: Grzyby zasiedlające owoce borówki wysokiej (Vaccinium corymbosum L.) uprawianej w południowo-wschodniej Polsce. Prog. Plant Prot. 47 (2): 380-384.

ZMARLICKI K. 2006: Produkcja i marketing borówki wysokiej w Europie USA i Kanadzie. Międzynarodowa Konferencja "Uprawa Borówki i Żurawiny". ISiK, Skierniewice.

Streszczenie: Ocena porażenia przez różne gatunki grzybów krzewów borówki wysokiej rosnacych na wybranych plantacjach towarowych zlokalizowanych $w$ centralnej Polsce. W latach 2017-2018 prowadzono badania dotyczące występowania chorób powodowanych przez grzyby na czterech plantacjach borówki wysokiej zlokalizowanych w centralnej Polsce. Celem badań była izolacja i identyfikacja patogenów z porażonych organów krzewów borówki wysokiej. W badanym materiale roślinnym zidentyfikowano cztery gatunki grzybów. Na wszystkich lustrowanych plantacjach obserwowano Botrytis cinerea, Godronia cassandrae i Phomopsis vaccinii, a tyl- ko na jednej plantacji zidentyfikowano Valdensia heterodoxa. Grzyby identyfikowano na podstawie oznak etiologicznych obecnych na porażonych organach roślin, przy użyciu klasycznych metod. W ramach badań oceniono skuteczność siedmiu fungicydów w zwalczaniu choroby szara pleśń borówki wysokiej. Do badań wykorzystano zarówno preparaty powszechnie polecane w ochronie borówki wysokiej przed szara pleśnią, jak i fungicydy dopuszczone do ochrony przed tą chorobą upraw innych roślin jagodowych (truskawka i malina). Fungicydy Luna Experience 400 SC i Prolectus 50 WG mogą być rozważane jako uzupełnienie listy środków zalecanych do zwalczania choroby szara pleśń na plantacjach borówki wysokiej.

Słowa kluczowe: Vaccinium corymbosum L., choroby grzybowe, ochrona chemiczna, Botrytis cinerea, Godronia cassandrae, Phomopsis vaccinii, Valdensia heterodoxa

MS received: 27.01 .2020

MS accepted: 14.09.2020

\section{Authors' address:}

Wioleta Lidia Piencek

(https://orcid.org/0000-0003-0610-8904)

Wojciech Kukuła

(https://orcid.org/0000-0002-5489-5343)

Zakład Fitopatologii

Instytut Nauk Ogrodniczych

Szkoła Główna Gospodarstwa Wiejskiego

w Warszawie

ul. Nowoursynowska 159, 02-776 Warszawa

Poland

e-mail: wioleta_piencek@sggw.edu.pl 